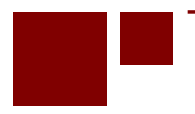

C E N T E R for

RETIREMENT

RESEARCH

at BOSTON COLLEGE

\title{
DO PEOPLE WORK LONGER WHEN THEY LIVE LONGER?
}

\author{
Damir Cosic, Aaron R. Williams, and C. Eugene Steuerle
}

CRR WP 2020-18

December 2020

\author{
Center for Retirement Research at Boston College \\ Hovey House \\ 140 Commonwealth Avenue \\ Chestnut Hill, MA 02467
}

Tel: 617-552-1762 Fax: 617-552-0191

https://crr.bc.edu

\begin{abstract}
All of the authors are with the Urban Institute. Damir Cosic is a senior research associate, Aaron R. Williams is a data scientist, and C. Eugene Steuerle is an Institute fellow and the Richard B. Fisher chair. The research reported herein was derived in whole or in part from research activities performed pursuant to a grant from the U.S. Social Security Administration (SSA) funded as part of the Retirement and Disability Research Consortium. The opinions and conclusions expressed are solely those of the authors and do not represent the opinions or policy of SSA, any agency of the federal government, the Urban Institute, or Boston College. Neither the United States Government nor any agency thereof, nor any of their employees, make any warranty, express or implied, or assumes any legal liability or responsibility for the accuracy, completeness, or usefulness of the contents of this report. Reference herein to any specific commercial product, process or service by trade name, trademark, manufacturer, or otherwise does not necessarily constitute or imply endorsement, recommendation or favoring by the United States Government or any agency thereof.
\end{abstract}

(C) 2020, Damir Cosic, Aaron R. Williams, and C. Eugene Steuerle. All rights reserved. Short sections of text, not to exceed two paragraphs, may be quoted without explicit permission provided that full credit, including (C) notice, is given to the source. 


\begin{abstract}
About the Center for Retirement Research
The Center for Retirement Research at Boston College, part of a consortium that includes parallel centers at the National Bureau of Economic Research, the University of Michigan, and the University of Wisconsin-Madison, was established in 1998 through a grant from the U.S. Social Security Administration. The Center's mission is to produce first-class research and forge a strong link between the academic community and decision-makers in the public and private sectors around an issue of critical importance to the nation's future. To achieve this mission, the Center conducts a wide variety of research projects, transmits new findings to a broad audience, trains new scholars, and broadens access to valuable data sources.
\end{abstract}

Center for Retirement Research at Boston College

Hovey House

140 Commonwealth Ave

Chestnut Hill, MA 02467

Tel: 617-552-1762 Fax: 617-552-0191

https://crr.bc.edu

Affiliated Institutions:

The Brookings Institution

Mathematica - Center for Studying Disability Policy

Syracuse University

Urban Institute 


\begin{abstract}
This paper examines the relationship between life expectancy and labor force participation at older ages. It uses information on life expectancy from the U.S. Small-Area Life Expectancy Estimates Project and information on labor force participation from the five-year American Community Survey. Critical components of the analysis include merging the Censustract-level information from the two data sets and estimating a spatial model of the relationship between life expectancy and labor force participation for men and women ages 55 to 74 that exploits the geographic variation in labor force participation and life expectancy. The main limitation of the study is that our analysis may understate the relationship between life expectancy and labor force participation to the extent that people are unaware of the geographic variation in life expectancy and, consequently, how it might affect their retirement planning.
\end{abstract}

The paper found that:

- A one-year increase in life expectancy increases labor force participation by about 1 percent for men ages 55 to 74. For women, labor force participation increases by 0.3 percent at ages 55 to 64 and decreases by about the same amount at ages 65 to 74 .

- Our non-linear model shows that the effect of life expectancy on male labor force participation increases with age, ranging from 0.8 percent for 55 -year-old men to 2.4 percent at age 74 . For women, it varies from zero at age 55 to 0.7 at 64 . At older ages, the effect for women does not vary with age.

The policy implications are:

- Our findings may help inform the Social Security Trustees' projections of future labor force participation.

- A spatial perspective may expand the understanding of the relationship between life expectancy and labor force participation. 


\section{Introduction}

Evidence from the past three decades in the United States points to at least a simple correlation between working longer and living longer, but if we look further back, that relationship becomes more ambiguous. Labor force participation within the older population has been growing over the last three decades in parallel with an increasing trend in life expectancy, but for more than a hundred years before that, these outcomes were moving in opposite directions: as life expectancy was growing, older adults were working less and retiring earlier. At the turn of the $20^{\text {th }}$ century, around half of Americans ages 62 to 69 were active in the labor force, but by century's end, that share had dropped to 30 percent (Figure 1). Over the same period, average life expectancy for this age group increased from 11.6 to 17.3 years. Of course, various other socioeconomic factors that affect labor force participation were changing over the last century, including industrialization and urbanization, the quality of retirement support, social norms about women's employment, and the prevalence of pensions that encourage early retirement. The main challenge in estimating the effect of life expectancy on labor force participation is isolating the contributions of all these other factors.

This study uses a novel approach in studying the relationship between life expectancy and labor force participation at older ages. Rather than analyzing changes over time, we rely on the spatial variation at a point in time. Because all observations were made under the same national macroeconomic conditions and with the same access to the federal safety net, this allows us to remove some of the key factors that confound a temporal analysis. Spatial analysis introduces its own set of confounding factors, but we believe that the available methods and data allow us to control for many of them and isolate their effects. We conducted this analysis using a dataset constructed by the U.S. Small-Area Life Expectancy Estimates Project (USALEEP) ${ }^{1}$ that contains estimates of life expectancy at the census-tract level. By combining it with data from the American Community Survey (ACS), we created a tract-level dataset that contains gender-specific labor force participation and demographic information for two age groups. We used multivariate regression analysis to estimate the effect of life expectancy on labor force participation at older ages.

Our results show that an additional year of life expectancy for men ages 55 to 74 increases their labor force participation rate by about 1 percent on average. The estimates for

\footnotetext{
${ }^{1}$ See National Center for Health Statistics (2018).
} 
women are smaller and more sensitive to how we specify the relationship. At ages 55 to 64 , women's labor force participation increases by 0.3 percent for each additional year of life expectancy, and at ages 65 to 74 the effect is slightly negative, on average, with significant variation across census-tract median household income.

The question we address has significance beyond academic research. The Social Security Board of Trustees (the Trustees henceforth) project a number of economic variables over a 75year horizon in their annual report and use forecasted increases in life expectancy to adjust their labor force participation projections. After projecting labor force participation for an age-gender group for some future year using a set of other factors, the Trustees add a longevity adjustment that equals 40 percent of the difference in the labor force participation rate for a longevityequivalent age-gender group in the reference year and the labor force participation rate being adjusted. The longevity-equivalent age-gender group is the group whose life expectancy in the reference year is the same as the projected life expectancy for the age-gender group of interest in the projection year. This method produces substantial increases in labor force participation at older ages (Steuerle and Quakenbush, 2012). Although this adjustment method seems reasonable, the Social Security Advisory Board $(2015,2017)$ characterized it as "ad hoc" and suggested conducting a study that would justify it, while acknowledging the challenges that such a study would entail. The present study contributes to that effort.

\section{Background}

\section{Trends in LFP}

Historically, labor force participation among older adults in the United States went through dramatic changes, and life expectancy was only one of many factors that shaped it. In the late $19^{\text {th }}$ century, a great majority of older men were working, but the share of older men employed fell over much of the $20^{\text {th }}$ century (Figure 2). In 1880, the labor force participation rate was 89 percent among men ages 62 to 69, and 94 percent among men ages 55 to 61 . Lee (2005) showed that the decline in older men's labor force participation at the turn of the $20^{\text {th }}$ century was caused largely by industrialization and the associated changes in the occupational composition of the labor force and sectoral composition of the economy. Women's labor force participation was generally low across all ages in the $19^{\text {th }}$ century and the first half of the $20^{\text {th }}$ century until it started rising in the second half of the $20^{\text {th }}$ century (Figure 2). However, 
aggregate data mask substantial heterogeneity by race and marital status. Goldin (1977) found that the labor force participation rate of nonwhite women remained virtually constant between 1890 and 1960 at around 40 percent. Over that period, participation increased for white married women as social norms about their place in society evolved (Fernández, 2013).

The emergence of retirement supports designed to provide resources to older people who are unable to work began with a significant expansion of veterans benefits in the last half of the 19th century, various modest old-age assistance programs in many states, and public sector pension plans in the early part of the 20th century. Private pension plan coverage also began in the last quarter of the $19^{\text {th }}$ century, though largely for a few long-term industrial workers in a society that was still largely agrarian. In the 1930s, many states created pension programs in the aftermath of the Great Depression. Social Security started paying benefits in 1940, and these benefits became more generous in the 1950s and 1960s, as Congress increased the real level of benefits several times, lowered the earliest age of eligibility to 62, and provided health care coverage to nearly all adults ages 65 and older. Many studies established a direct link between the generosity of Social Security and Medicare benefits and labor force participation, although their estimates of the magnitude varied from modest (Krueger and Pischke, 1992; Blau and Goodstein, 2010) to strong (Boskin, 1986; Masterbuoni, 2009; and Cosic and Steuerle, forthcoming). An additional factor that increased retirement incentives was the increasing prevalence, generosity and maturation of private-sector pensions after World War II. The share of private-sector workers covered by defined benefit pensions, which were structured in a way that usually discouraged work after a certain age, increased from 25 percent in 1950 to 45 percent in 1970 (Employee Benefits Research Institute, 1998).

The growth in generous public and private pensions came to an end in the 1980s. The Social Security reforms of 1983 increased the program's full retirement age over a 22-year period, though just at about the rate of projected increase in longevity over that span, and decreased benefits for those who claim early, although these changes did not affect anyone reaching age 62 before 2000. Private firms also started shifting from defined benefit pensions to 401(k) or other defined contribution plans, which have less disincentivizing effect on workers, and also started removing early retirement benefits. Hurd and Rohwedder (2011) estimated that the shift from DB pensions to DC retirement plans explains two thirds of the increase in labor force participation at age 62 between 1992 and 2004 . 


\section{Trends in Life Expectancy}

Life expectancy in the United States has been increasing for more than two centuries (Goss et al., 2016), although it has recently stagnated and even decreased for some groups. Life expectancy at birth increased from 46 years for men and 49 years for women in 1900, to 76 years for men and 81 years for women in 2015 (Office of the Chief Actuary, 2018). Over the same period, at age 65 life expectancy grew from 11 years for men and 12 years for women, to 18 years for men and 20 years for women. This growth, however, has not been uniform across the population. Waldron (2007) showed that life expectancy at age 60 increased between the 1912 and 1941 birth cohorts more than three times as fast for the top half of the earnings distribution as for the bottom half. Case and Deaton (2017) showed that life expectancy decreased since 2000 for the middle aged, white non-Latinx population without a college education. Woolf and Schoomaker (2019) show that mortality for age groups 5 to 44 and 55 to 64 increased between 2010 and 2017.

\section{Life Expectancy and LFP}

There are two main mechanisms through which increases in life expectancy can raise labor force participation at older ages. The first one assumes that individuals choose their retirement age by optimizing their lifetime utility, and that their individual expectation of longevity corresponds to actuarial life expectancy. The lifetime optimization includes saving for retirement, forming expectations of longevity and future income, and weighing the disutility of working at older ages against the need to adequately fund retirement. It is easy to show that an increase in an individual's longevity expectations should induce them to postpone their retirement age. Otherwise, the individual would have to fund a longer retirement with the same amount of retirement savings, assuming that older workers have little room for increasing their retirement savings by changing their saving rate.

These theoretical results have been confirmed by empirical research. Hamermesh (1985) showed that people's subjective longevity expectations track the actuarial life expectancy fairly well, although he used a nonrepresentative sample of the U.S. population. More recent studies by Khan, Rutledge, and Wu (2014) and Van Solinge and Henkens (2010) used longitudinal surveys of older workers to show that people adjust their retirement plans according to changes in subjective longevity expectations. Both studies found that an increase in subjective life 
expectancy increased participants' planned retirement ages and their expectations of working at older ages. Actual behavior, however, seems to be less sensitive to changes in life expectancy. Van Solinge and Henekens (2010) found no significant effect of subjective life expectancy on the actual retirement age, and Khan et al. (2014) found this effect to be weaker than the effect on the expected retirement age. Of course, the life cycle model assumes that work provides disutility, and comparisons of work effort over time ignore the changing nature of work and the extent to which it might provide disutility. Studies of wealth holding, bequest motives, and the behavior of the rich (Baranzini, 2005) also show that most saving cannot be explained by the life cycle model.

The second way that life expectancy affects labor force participation is through health and capacity for work. Life expectancy is closely related to the overall health of the population. A lower prevalence of chronic diseases such as obesity, heart disease, and diabetes reduces mortality and increases life expectancy. Health is also one of the key factors in an individual's decision to work. A medical condition may limit or prevent some types of work, and poor health generally increases the disutility of work (Van den Berg et al., 2010).

Building on this relationship between life expectancy or health, on the one side, and labor force participation on the other, several studies defined a potential labor force participation rate as the rate that would have prevailed if a person's work decision had depended only on capacity for work. Assuming that people of similar ages with the same health status and demographic characteristics have the same capacity for work, Cutler, Meara, and Richards-Shubik (2011) found that the potential labor force participation rate for older adults was significantly higher than the actual rate. In particular, they estimated that adults ages 62 to 64 could increase their labor force participation by 15 percentage points. Milligan and Wise (2012) use a similar approach in their cross-country study, but they control for life expectancy rather than health. Coile, Milligan, and Wise (2016) compared the two methods on the same sample and found the latter to produce substantially higher estimates of potential labor force participation. Similarly, Cushing-Daniels and Steuerle (2010) found that controlling for life expectancy instead of chronological age reveals a more dramatic decrease in labor force participation among older men over the second half of the $20^{\text {th }}$ century. 


\section{Data}

We combined demographic and economic data from the Census Bureau and life expectancy data from the National Center for Health Statistics at the census tract level to examine the relationship between life expectancy and labor force participation. Other data sources were used to aggregate geographies, align geographies over time, and classify geographies according to urbanicity.

We used life expectancy data by age group, sex, and census tract created by the National Center for Health Statistics (2018). The USALEEP contains abridged period life expectancy tables for 11 age groups and 65,662 census tracts (88.7 percent of all U.S. census tracts) between 2010 and 2015. Census tracts in Maine and Wisconsin were excluded because geocoding of death records in these states did not start until 2011. An additional 222 census tracts were excluded because their six-year pooled population sizes did not exceed 5,000, and 764 census tracts were excluded because the standard error of life expectancy at birth exceeded 4.0. In addition, for each age-gender group, we dropped census tracts with less than 100 people in the group and those with a zero labor force participation rate for the group.

Arias et. al (2018) released a detailed description of the methods used to create the file. Estimates were created in several steps. First, they geocoded death records from 2010 to 2015 to census tracts. Second, they generated population estimates for each census tract using the 2010 decennial census and 2011 to 2015 ACS. Third, they estimated Poisson and negative binomial models of death rates and used them to impute age-specific death counts when the observed agespecific death count was zero. Finally, methods developed by Chiang (1984) were used to estimate abridged life tables.

Our quality-control analysis of this dataset matched the results of Arias et. al (2018) and confirmed high data quality. Life-expectancy within census tracts follows expected patterns, there were no aberrations at the state or national level, and the weighted mean values of life expectancy at the state and national levels match state and national estimates. For example, the weighted mean life expectancy of the census tracts is 78.7 years and the official U.S. estimate for midyear 2013 is 78.8 years (Arias et. al, 2018). Our key predictor variable, life expectancy by age-gender groups (ages 55 to 64 and 65 to 74, separately for men and women), comes directly from USALEEP. 
Most other variables used in this study come from the 2011 to 2015 five-year ACS at the census tract level. ${ }^{2}$ We calculated the labor force participation rate for each age-gender group and census tract as the ratio of the number of people in the labor force to the overall population. The relationship between labor force participation and life expectancy is illustrated by Figure 3, which shows scatterplots of the two variables and a smoothed trend line by age-gender group. Although the magnitude of the two variables differ across the four groups, they all exhibit positive correlation between life expectancy and labor force participation for lower values of life expectancy and a plateau for higher values. Table 1 shows summary statistics of all variables by age-gender group.

We constructed prime-age employment rates for ages 25 to 54 from population counts and employment rates for ages 25 to 29, ages 30 to 34, ages 35 to 44, and ages 45 to 54, all of which were obtained from the ACS published tables. We estimated the median prime-age employment rate and designated census tracts with an employment rate below the median as low-employment areas.

The ACS's published profile tables provide information on various socioeconomic characteristics. They report the educational attainment of the population ages 25 years and older by census tract. We obtained the share of the population living in poverty directly from the published ACS five-year profile tables. It represents the proportion of people in a census tract who live in households whose income over the 12 months prior to the survey was below the federal poverty level. The share of non-Latinx ${ }^{3}$ White people is directly reported on the published ACS five-year profile tables as the percentage of the population who is "Not Hispanic or Latino" and "White alone". Median household income by census tract is also directly reported in the ACS tables, which we used for classification of tracts into quartiles of median household income.

The share of people with disabilities in a census tract is also reported on the ACS fiveyear profile tables. Disability is defined as having difficulty with at least one of the following six activities: hearing, vision, cognitive, ambulatory, self-care (difficulty with two or more activities

\footnotetext{
${ }^{2}$ We also used employment and population counts by age and sex from the 2005-2009 five-year ACS to calculate the labor force participation rate for lagged dependent variable design. All ACS variables were obtained from the Census Bureau's application programming interface (API) using the censusapi R package (Recht, 2019).

${ }^{3}$ This paper uses the term Latinx to describe people of Latin American descent because it is the most inclusive term with respect to ethnicity and gender.
} 
of daily living), or having difficulty living independently (difficulty with two or more instrumental activities of daily living).

We mapped census tracts to commuting zones, as defined by U.S. Department of Agriculture's Economic Research Service, for estimating fixed-effects regression models and robustness checks. Commuting zones are combinations of counties and county equivalents that are intended to capture regional economic and labor markets rather than solely municipal or state boundaries. Every census tract belongs to only one commuting zone. Figures 4 and 5 show maps of the U.S. with color-coded values of life expectancy and labor force participation by agegender group. The Figures reveal significant differences across the country and a moderate level of correlation between life expectancy and labor force participation.

\section{Methods}

We use a multivariate regression framework to analyze the relationship between life expectancy and labor force participation. The unit of observation is a census tract, the dependent variable is the labor force participation rate for people in a given age-gender group who lived in the tract at the time of the ACS survey, and the main independent variable is the average life expectancy for the same group. For identification, we rely on the variation of these variables within commuting zones and within states. Under the assumption that states affect labor force participation by their legislative and regulatory framework and commuting zones approximate geographic boundaries of local labor markets, we include state and commuting zone indicators to remove cross-state and cross-commuting-zone variation. This framework does not allow us to identify mechanisms through which life expectancy affects labor force participation.

Labor force participation at older ages is affected by a number of factors other than life expectancy. To the extent that these factors are correlated with life expectancy, omitting them from a regression would bias the estimated effect of life expectancy. Seniors with higher educational attainment generally retire later that those with less education because they are more likely to work in occupations that are less physically demanding. Because educational attainment is also highly correlated with life expectancy (Meara, Richards, and Cutler, 2008), we include in our regressions the share of people who have no more than a high-school diploma by census tract and age-gender group. The age composition of an age-gender group is also correlated with both labor force participation and life expectancy. The publicly available ACS 
data do not allow us to fully adjust for differences in the age composition, but they do indicate population shares in more narrowly defined age groups (55-59, 60-61, 62-64, 65-69, and 70-74), which we include in the regressions. We also control for urbanicity by including indicators for metro, large non-metro (population 20,000 or more) and small non-metro (population less than $20,000)$ areas. We include the prime-age employment rate by census tract to control for microgeographic variation in economic conditions.

There are other confounding factors whose relationship with life expectancy is useful in explaining life expectancy's effect on labor force participation. One such factor is health, which is a key determinant of labor force participation at older ages, and it is closely correlated with life expectancy. In fact, we consider health one of the main mechanisms through which life expectancy affects labor force participation. Consequently, we do not make an effort to isolate its effect on labor force participation from the effect of life expectancy. Income is another variable that is correlated with both variables of interest.

Formally, we regress labor force participation $y_{t z s}^{(g)}$ for age-gender group $g$ in tract $t$ commuting zone $z$ and state $s$ on some function of life expectancy $f\left(e_{t z s}^{(g)}\right)$, a set of tract-specific characteristics $X_{t z s}^{(g)}$, state fixed effects $\lambda_{s}$, and commuting-zone fixed effects $\eta_{z}$, while $\varepsilon_{t z s}$ represents the error term:

$$
y_{t z s}^{(g)}=f\left(e_{t z s}^{(g)}\right)+X_{t z s}^{(g)} \beta+\lambda_{s}+\eta_{z}+\varepsilon_{t z s}
$$

Choosing a suitable functional form for the relationship between life expectancy and labor force participation is of key importance for the estimation of this equation. As it can be seen in Figure 3 , this relationship is unlikely to be linear, and imposing linearity would underestimate the effect in lower ranges of life expectancy and overestimate it in upper ranges. Because economic theory offers little guidance, we explored several functional forms. On the right-hand side of the equation, we used linear, logarithmic, and quadratic transformations for life expectancy. On the left-hand side, we used linear, logarithmic, and logit (i.e., log odds ratio) transformations. For each functional form, we estimated several specifications that include different subsets of regressors and their interactions with life expectancy. We report results for the specifications with the highest adjusted $\mathrm{R}^{2}$. In addition, we report results from the baseline specification that 
contains a minimal set of regressors, uses linear form for life expectancy, and logarithmic transformation of labor force participation. Although the baseline regression is not the best fit, its value is in the simplicity of its interpretation.

\section{Results}

We first present the estimates of the baseline specification that includes only a linear term for life expectancy and no interactions with income or employment rates. These estimates are useful for comparing age-gender groups, and they offer a straightforward interpretation of the coefficients. Because the labor force participation rate is expressed in log form, the coefficient on life expectancy can be interpreted as the percentage change in the labor force participation rate associated with a one-year increase in average life expectancy. Table 2 shows these estimates for the four age-gender groups. For women ages 55 to 64, an additional year of life expectancy raises their labor force participation rate by 0.3 percent. For men in both age groups, an additional year of life expectancy increases the labor force participation rate by about 1 percent. The estimated effect for women ages 65 to 74 has the opposite sign, indicating that an additional year of life expectancy reduces labor force participation by 0.2 percent. Even though the two variables are positively correlated, once we remove the cross-state variation the correlation becomes negative. This unexpected result, for which we currently cannot provide a good explanation, has been consistent for this group, except in specifications that interact life expectancy with median-income quartiles. When the effect of life expectancy is allowed to vary with the tract median household income, it has a negative sign in census tracts with median income in the bottom half of the distribution, and a positive sign for those in the upper half of the distribution. Other coefficients in the baseline specification, with the exception of urbanicity, are statistically significant and have the expected signs. The area's prime-age employment rate, which is an indicator of local economic activity and labor demand, is positively correlated with labor force participation at older ages. The effect of educational attainment is also positive (i.e., the coefficient on the share of people with at most a high school education is negative), which is consistent with findings in the literature, while the age composition indicators confirm that labor force participation decreases with age. Urbanicity is statistically significant only at ages 65 to 74 , and it indicates a higher labor force participation rate in large nonmetro areas than in metro areas. 
Table 3 shows, for each age-gender group, estimates of the specification with the best fit as measured by the adjusted $\mathrm{R}^{2}$. The functional form of the dependent variable is logarithmic for all groups. The best-fitting functional form for life expectancy is a second-degree polynomial for all groups except women ages 65 to 74, for whom a linear form achieved the best fit. The best fitting specifications for all groups included interactions of life expectancy with other variables. For women, allowing the effect of life expectancy to vary with income helped explain the biggest part of the variation in the labor force participation rate, while for men, the interaction of life expectancy and the indicator for a low-employment area achieved the best fit. In addition to these interactions and the regressors from the baseline specification, the best fitting specifications include the share of people with disability per tract, the share of non-Latinx White people, the share of people living in poverty, and the logarithm of median household income in the regressions for men. The estimated effects of life expectancy on labor force participation have the same sign and similar magnitude as in the baseline specification. One noticeable change is that allowing the coefficient on life expectancy to vary with income shows that the effect of life expectancy on labor force participation is positive for women age 65 to 74 who live in the half of tracts with the highest median household income. For those in the bottom half, the effect is negative as in the baseline specification.

The effect of an additional year of life expectancy in the regressions with a quadratic form in life expectancy changes with age because life expectancy decreases with age. Because the coefficient on the quadratic term is negative, the effect is smaller at younger ages and increases with age. Figure 6 shows the effect of an additional year of life expectancy on labor force participation rate based on the results from table 3 and compares them to the effects implied by the Trustees' life expectancy add factor. For women, it ranges from zero at age 55 to around 0.7 percent at age 64. For women ages 65 to 75, the effect does not vary with age, because adding a square term in life expectancy did not improve the fit, but it varies with tract median household income. The effect is negative for the bottom two quartiles of median income, -1.0 and -0.38 , respectively. The value for the third quartile, which is shown in Figure 6 , is 0.32 percent and 0.18 for the fourth quartile. For men, the effect increases from 0.80 percent at age 55 to 1.80 percent at age 64 , and from 1.50 percent at age 65 to 2.25 percent at age 74. As Figure 6 shows, our estimates for men are comparable to the effect implied by the Trustees' assumptions, but for women they are significantly smaller at most ages. 
One must be careful in interpreting these results and comparing them with the Trustees' projections or studies that use time-series data. Our estimates have the advantage and disadvantage of being computed for a single point in time and so must be used with caution when projecting outcomes over time. One advantage of spatial analysis is that it allows isolating the effect of longevity from time-varying factors that may interact with life expectancy and whose effects are difficult to identify in time-series data. For example, a "herd effect" may reduce the effect of an increase in life expectancy or create inertia that causes its delay, and changes in demand for older workers' labor may confound the relationship between life expectancy and labor force participation. Because these factors generally don't vary much on the census-tract level, they most likely do not affect our estimates. But this can be a disadvantage when estimates are used for projecting future outcomes, in which case the combined effect of life expectancy and its interactions with other variables may be more desirable.

\section{Conclusion}

Our findings indicate that people work longer when they live longer, but this conclusion comes with caveats. The relationship between labor supply and life expectancy is complex and multifaceted, and this study offers but one perspective. Life expectancy can affect labor force participation in multiple ways, and these two variables move at different paces over time, and they are correlated with many of the same confounding variables. Our choice of data and methods brings some aspects of this question into sharper focus but inevitably blurs others; it removes some time-varying confounding variables but may introduce others that vary across space. In particular, it is not clear that our approach captures the optimization of lifetime utility, which is one of the main mechanisms through which life expectancy affects labor force participation at older ages. Because there is no evidence that people are aware of the geographic variation in life expectancy, it is possible that our estimates capture only its correlation with health and its effect on the capacity to work - thus underestimating the total effect on labor force participation - and should be considered a lower bound for the total effect. The lack of evidence is due to the lack of research in this area, which points to a direction for future investigation.

Another issue that requires further attention is the negative sign of the effect of life expectancy on labor force participation for women ages 65 to 74 . Although this result may be a true reflection of a phenomenon that is waiting for a theoretical explanation, it is more likely that 
our functional specifications failed to capture the true nature of the relationship between life expectancy and labor force participation for this age-gender group, or that some of the assumptions we made in our effort are invalid. Despite these caveats, our results may expand the understanding of this important question and help inform the Trustees' projections of future labor force participation. 


\section{References}

Arias, E., L. A. Escobedo, J. Kennedy, C. Fu, and J. Cisewski. 2018. "U.S. Small-Area Life Expectancy Estimates Project: Methodology and Results Summary.” Vital Health Stat 2(181). Hyattsville, MD: National Center for Health Statistics.

Baranzini, Mauro. 2005. "Modigliani's Life Cycle Theory of Savings Fifty Years Later.” BNL Quarterly Review LVIII: 109-172.

Bell, Felicitie C. and Michael L. Miller. 2005. "Life Tables for the United States Social Security Area 1900-2100.” Actuarial Study No. 120. Baltimore, MD: U.S. Social Security Administration, Office of the Chief Actuary.

Berg, Tilja van den, Merel Schuring, Mauricio Avendano, Johan Mackenbach, and Alex Burdorf. 2010. "The Impact of Ill Health on Exit from Paid Employment in Europe among Older Workers." Occupational and Environmental Medicine 67(12): 845-852.

Blau, David M. and Ryan M. Goodstein. 2010. "Can Social Security Explain Trends in Labor Force Participation of Older Men in the United States?" Journal of Human Resources 45(2): 328-363.

Case, Anne and Angus Deaton. 2017. "Mortality and Morbidity in the 21st Century." Brookings Papers on Economic Activity. Washington, DC: The Brookings Institution.

Chiang, Chin Long. 1984. The Life Table and Its Applications. Malabar, Fla: R.E. Krieger Pub. Co.

Clark, Robert L., Lee A. Craig, and Jack W. Wilson. 2003. "A History of Public Sector Pensions in the United States." Philadelphia, PA: The Wharton School of the University of Pennsylvania, Pension Research Council.

Coile, Courtney, Kevin S. Milligan, and David A. Wise. 2016. "Health Capacity to Work at Older Ages: Evidence from the U.S." Working Paper 21940. Cambridge, MA: National Bureau of Economic Research.

Cosic, Damir and C. Eugene Steuerle. 2020 (forthcoming). "The Effect of Early Claiming Benefit Reduction on Retirement." Working Paper. Chestnut Hill, MA: Center for Retirement Research at Boston College.

Cushing-Daniels, Brendan and C. Eugene Steuerle. 2010. "Retirement and Social Security: A Time Series Approach Based on Remaining Life Expectancy." Urban Institute.

Cutler, David, Ellen Meara, and Seth Richards-Shubik. 2011. "Healthy Life Expectancy: Estimates and Implications for Retirement Age Policy.” Working Paper NB10-11. Cambridge, MA: National Bureau of Economic Research, Retirement Research Center.

Fernández, Raquel. 2013. "Cultural Change as Learning: The Evolution of Female Labor Force Participation over a Century.” American Economic Review 103(1): 472-500. 
Georgetown University Law Center. 2010. "A Timeline of the Evolution of Retirement in the United States." Workplace Flexibility.

Goldin, Claudia. 1977. "Female Labor Force Participation: The Origin of Black and White Differences, 1870 and 1880." The Journal of Economic History 37(1): 87-108.

Goss, Stephen, Karen Glenn, Michael Morris, K Mark Bye, and Felicitie Bell. 2016. "Human Longevity and Implications for Social Security Actuarial Status." Actuarial Note 158. Baltimore, MD: U.S. Social Security Administration, Office of the Chief Actuary.

Hamermesh, Daniel S. 1985. "Expectations, Life Expectancy, and Economic Behavior." The Quarterly Journal of Economics 100(2): 389-408.

Khan, Mashfiqur, Matthew S. Rutledge, and April Yanyuan Wu. 2014. "How Do Subjective Longevity Expectations Influence Retirement Plans?" Working Paper 2014-1. Chestnut Hill, MA: Center for Retirement Research at Boston College.

Lee, Chulhee. 2005. "Labor Market Status of Older Males in the United States, 1880-1940." Social Science History 29(1): 77-105.

Meara, Ellen R., Seth Richards, and David M. Cutler. 2008. "The Gap Gets Bigger: Changes in Mortality and Life Expectancy, by Education, 1981-2000." Health Affairs 27(2): 350360.

Milligan, Kevin S. and David A. Wise. 2012. "Health and Work at Older Ages: Using Mortality to Assess the Capacity to Work across Countries." Working Paper 18229. Cambridge, MA: National Bureau of Economic Research.

Montez, Jennifer Karas, Robert A. Hummer, Mark D. Hayward, Hyeyoung Woo, and Richard G. Rogers. 2011. "Trends in the Educational Gradient of U.S. Adult Mortality From 1986 Through 2006 by Race, Gender, and Age Group." Research on Aging 33(2): 145-171.

National Center for Health Statistics, ed. 2018. "U.S. Small-Area Life Expectancy Estimates Project (USALEEP): Life Expectancy Estimates File for the US, 2010-2015." Hyattsville, MD.

Office of the Chief Actuary. 2018. “Actuarial Life Table.” Baltimore, MD: U.S. Social Security Administration.

—. 2019. "The Long-Range Economic Assumptions for the 2019 Trustees Report." Baltimore, MD: U.S. Social Security Administration.

Recht, Hannah. 2019. "Censusapi.” Comprehensive R Archive Network (CRAN). Available at: https://cran.r-project.org/web/packages/censusapi/index.html

Rijn, Rogier M van, Suzan J W Robroek, Sandra Brouwer, and Alex Burdorf. 2014. "Influence of Poor Health on Exit from Paid Employment: A Systematic Review." Occupational and Environmental Medicine 71(4): 295-301. 
Solinge, Hanna van, and Kène Henkens. 2010. "Living Longer, Working Longer? The Impact of Subjective Life Expectancy on Retirement Intentions and Behaviour." European Journal of Public Health 20(1): 47-51.

Steuerle, C. Eugene and Caleb Quakenbush. 2012 "Correcting Labor Supply Projections for Older Workers Could Help Social Security and Economic Reform. Program on Retirement Policy Brief \# 35. Washington, DC: Urban Institute.

U.S. Social Security Advisory Board. 2015. "Report of the 2015 Technical Panel on Assumptions and Methods." Washington, DC.

—. 2017. "Technical Panel on Labor Force Participation." Washington, DC. 


\section{Figures}

Figure 1. Labor Force Participation Rate and Life Expectancy at Ages 62 to 69

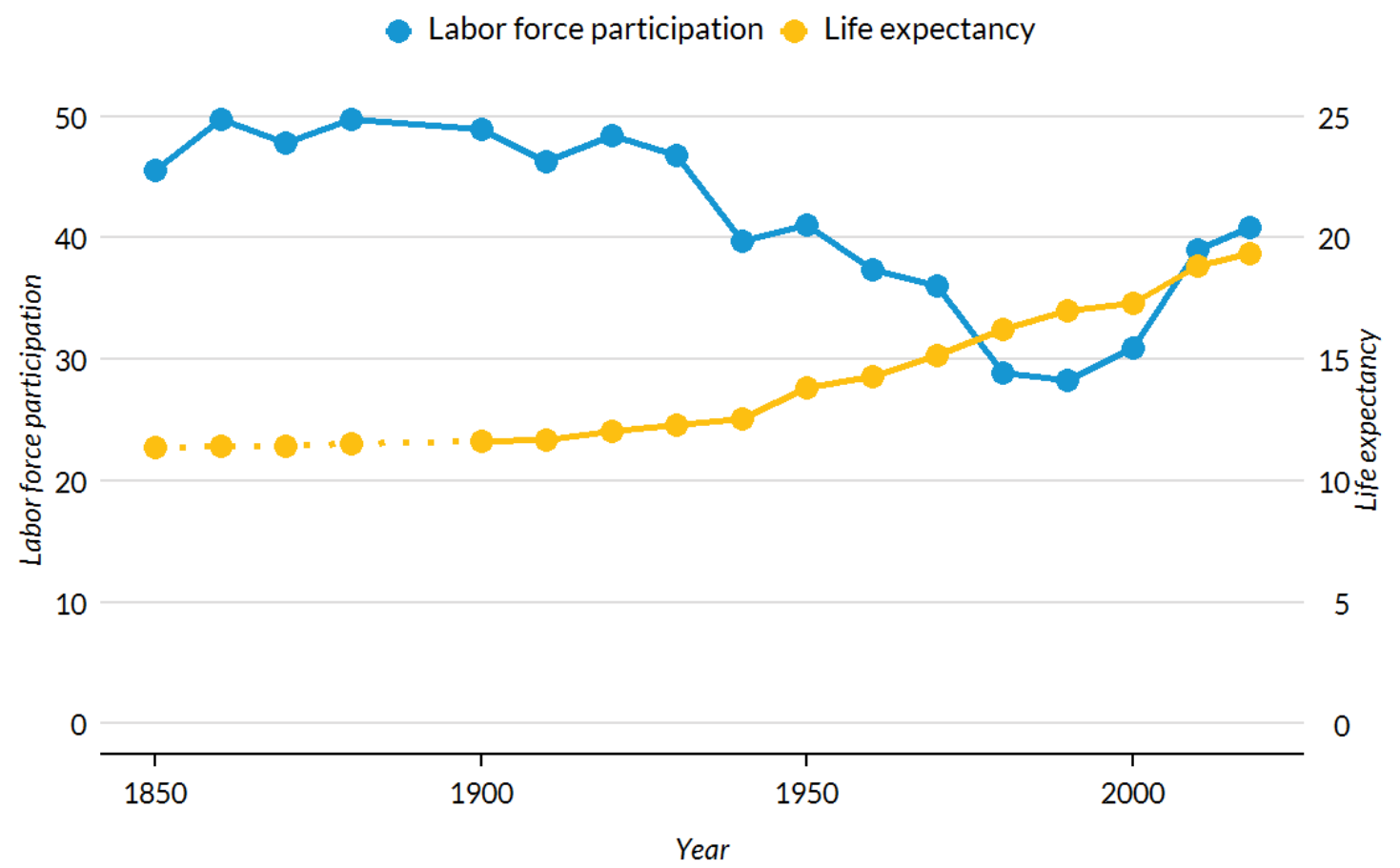

Notes: The dotted line represents extrapolated values. The censuses of 1850 and 1860 enumerated enslaved African Americans in a separate population schedule, which is not included in the data used in this paper.

Sources: Decennial Census and American Community Survey (1850-2018), Social Security Cohort Life Tables. 
Figure 2. Labor Force Participation Rate and Life Expectancy at Age 65

Men

Labor force participation Life expectancy

100

20

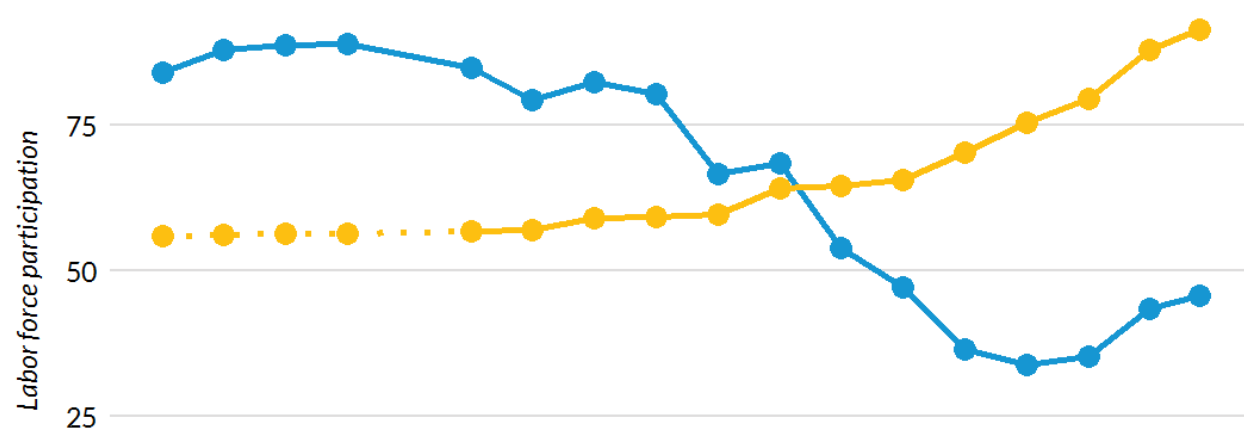

15

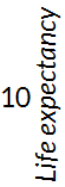

5

0

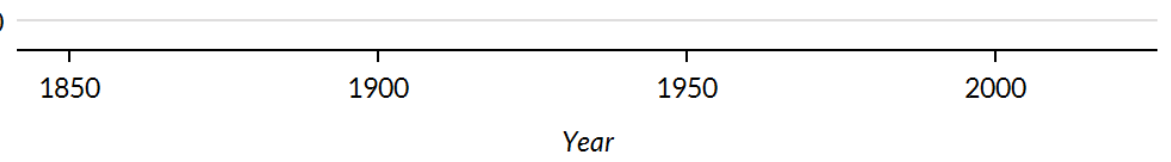

0

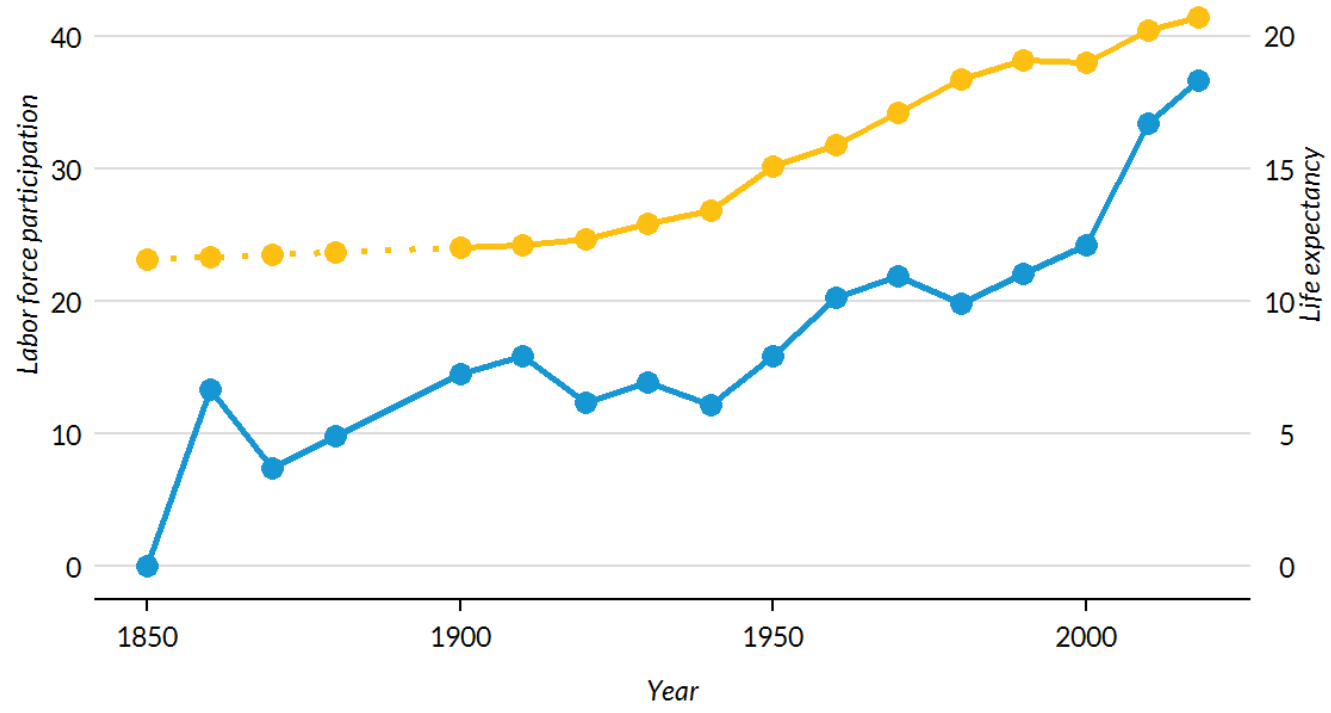

Notes: The dotted line represents extrapolated values. The censuses of 1850 and 1860 enumerated enslaved African Americans in a separate population schedule, which is not included in the data used in this paper.

Sources: Decennial Census and American Community Survey (1850-2018), Social Security Cohort Life Tables. 
Figure 3. Labor Force Participation Rate and Life Expectancy by Census Tract, 2011-2015

\section{Women Ages 55-64}

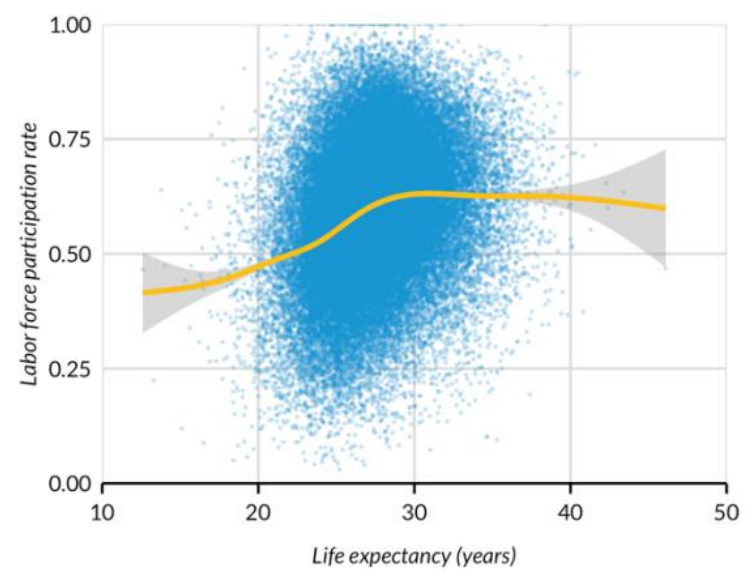

\section{Women Ages 65-74}

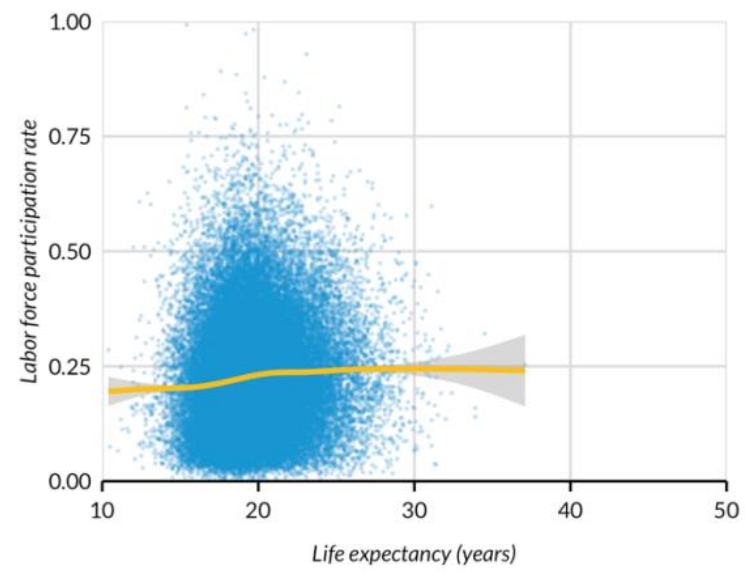

Men Ages 55-64

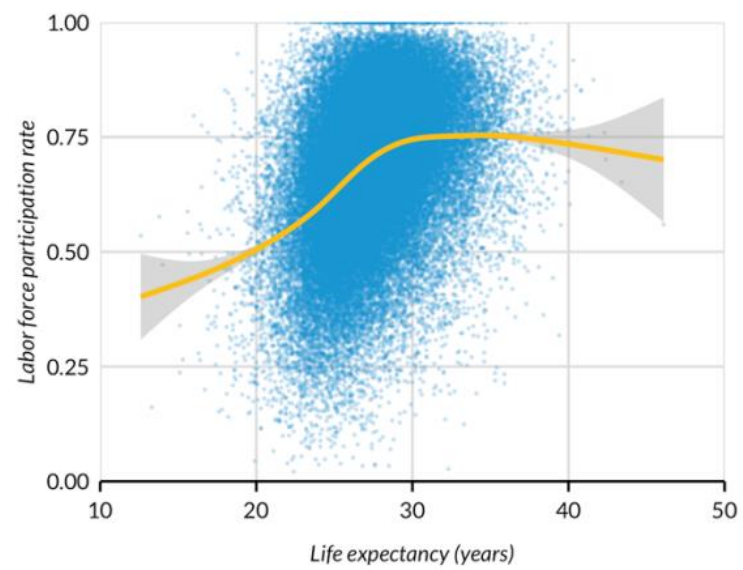

Men Ages 65-74

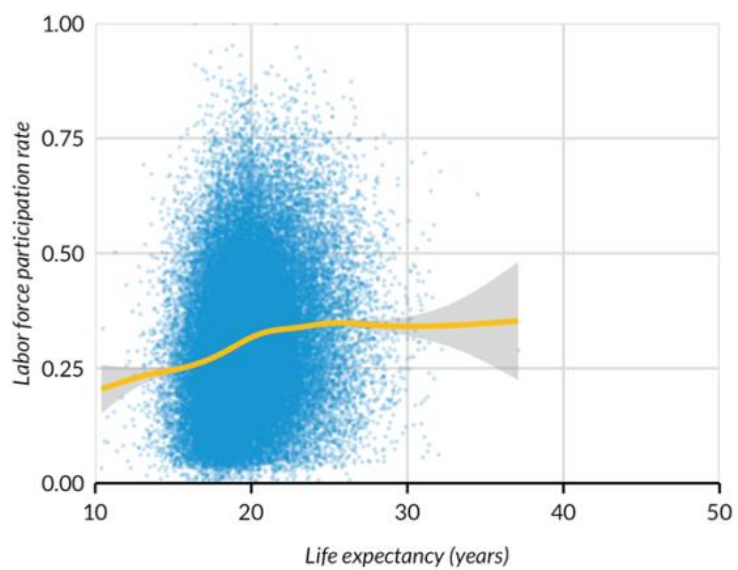

Note: The yellow trend curve is estimated with a penalized cubic regression spline with shrinkage and evenly spaced splines.

Sources: USALEEP and ACS (2011-2015). 
Figure 4. Labor Force Participation Rate and Life Expectancy for Ages 55 to 64 by Commuting Zone, 2011-2015

Life Expectancy (years), Women Ages 55-64

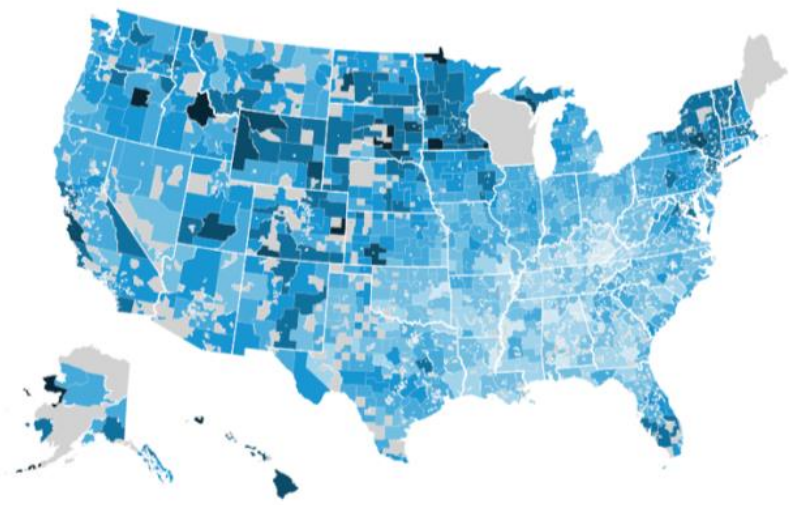

Life Expectancy (years), Men Ages 55-64

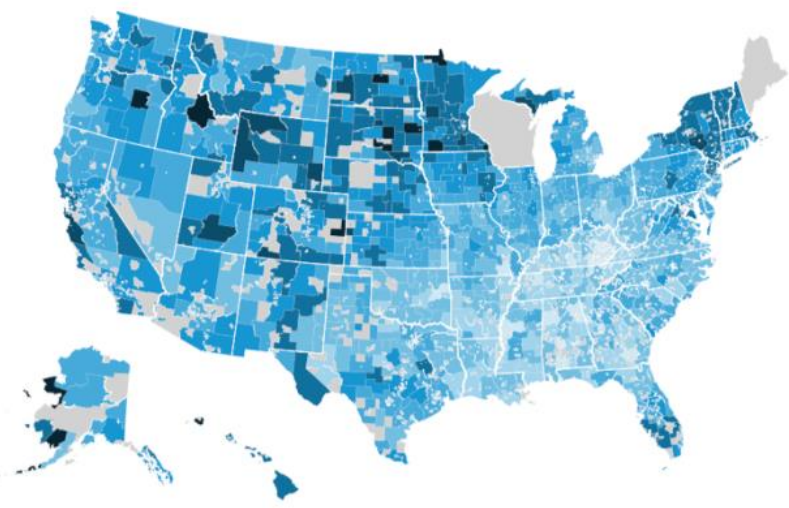

Sources: USALEEP and ACS (2011-2015).
Labor force participation (\%), Women Ages 55-64

$<=25$

25-26

26-27

$27-28$

28-29

29-30

30-31

$31+$

NA

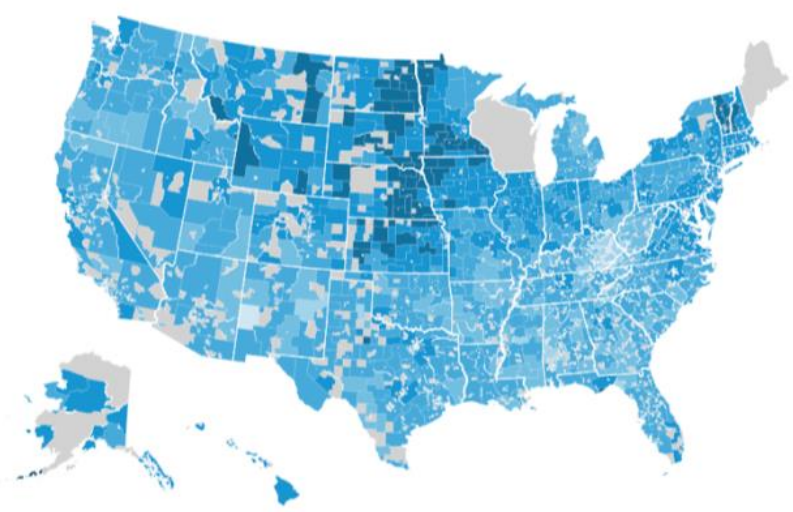

$<=30$

$30-40$

40-50

50-60

60-70

$70-80$

$80-90$

$90+$

NA
Labor force participation (\%), Men Ages 55-64

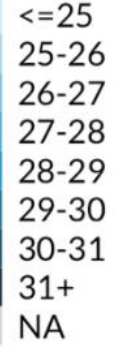

$<=25$

$27-28$

28-29

29-30

NA

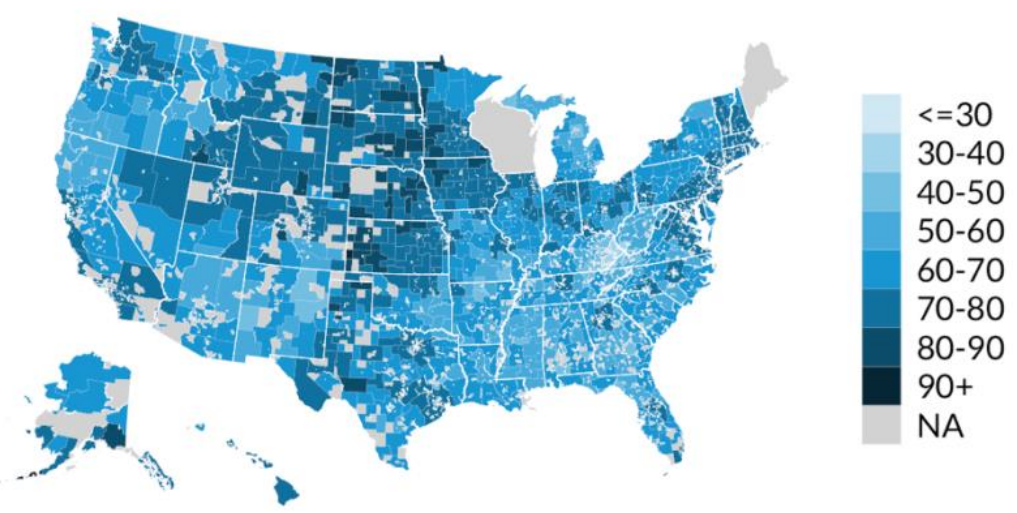


Figure 5. Labor Force Participation Rate and Life Expectancy for Ages 65 to 74 by Commuting Zone, 2011-2015

Life Expectancy (years), Women Ages 65-74

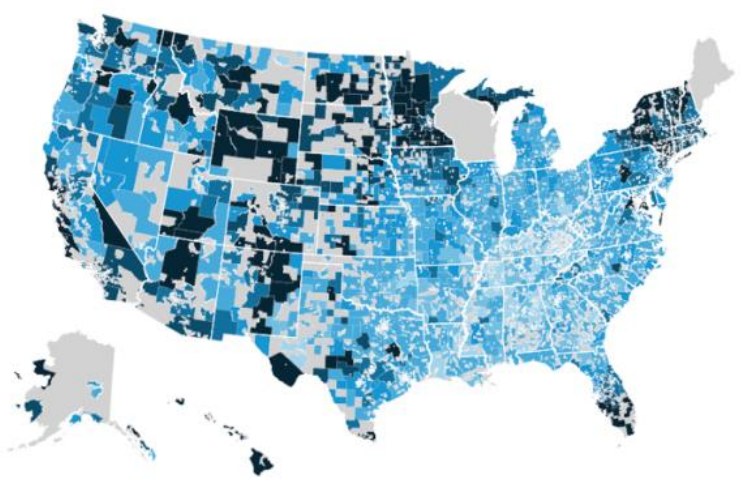

Life Expectancy (years), Men Ages 65-74

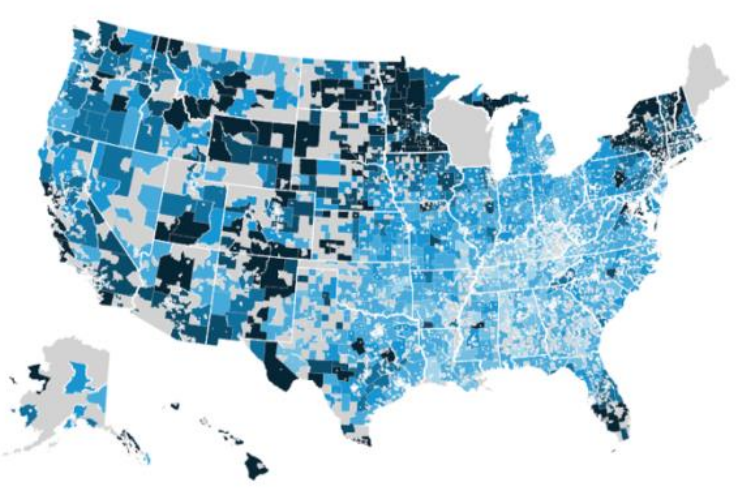

$$
<=18
$$

18.0-18.5

$18.5-19.0$

$19.0-19.5$

$19.5-20.0$

20.0-20.5

20.5-21.0

$21+$

NA
Labor force participation (\%), Women Ages 65-74

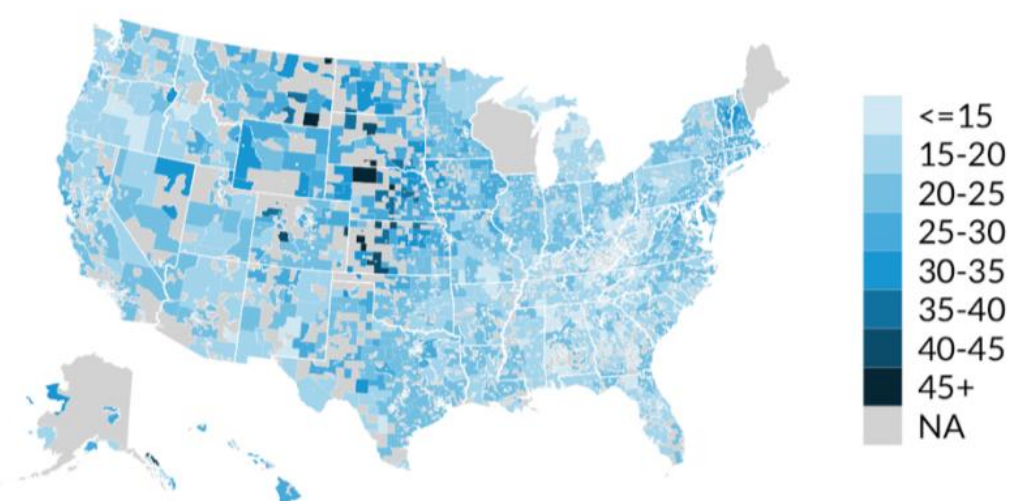

Labor force participation (\%), Men Ages 65-74

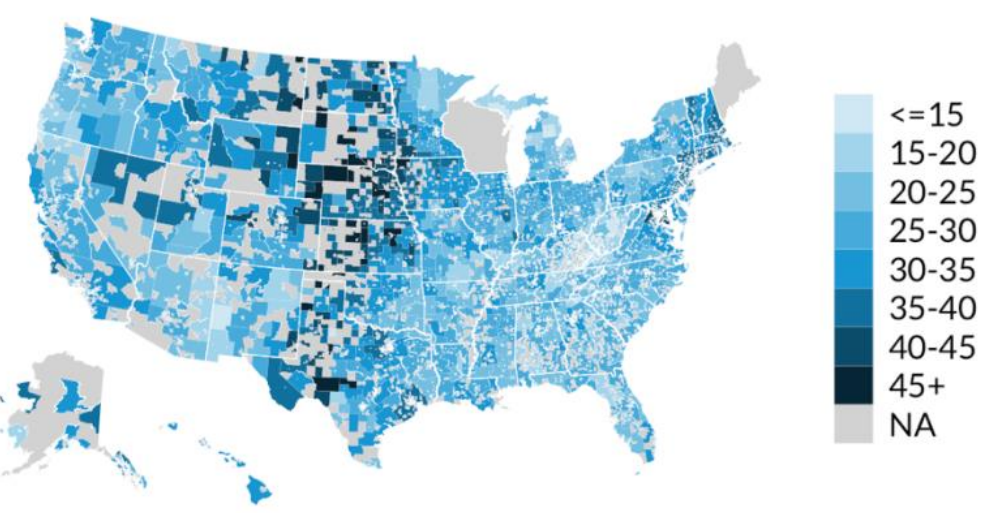

Sources: USALEEP and ACS (2011-2015). 
Figure 6. Estimated Effect of a One-Year Increase in Life Expectancy on Labor Force Participation

Men

Trustees Urban

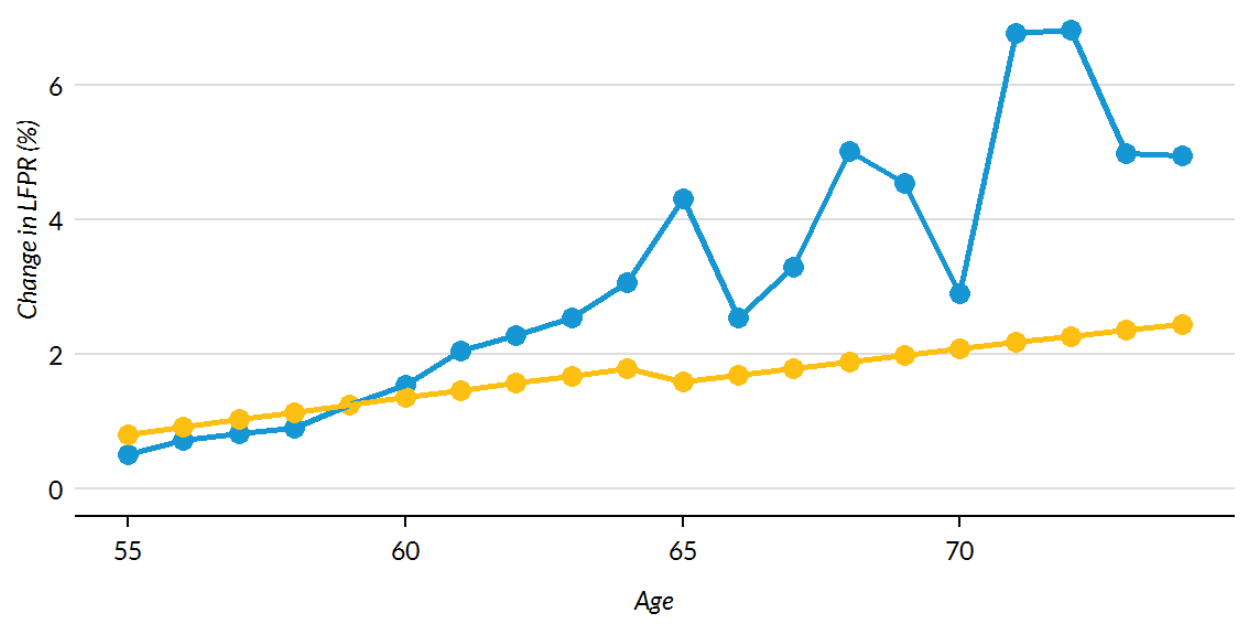

Women

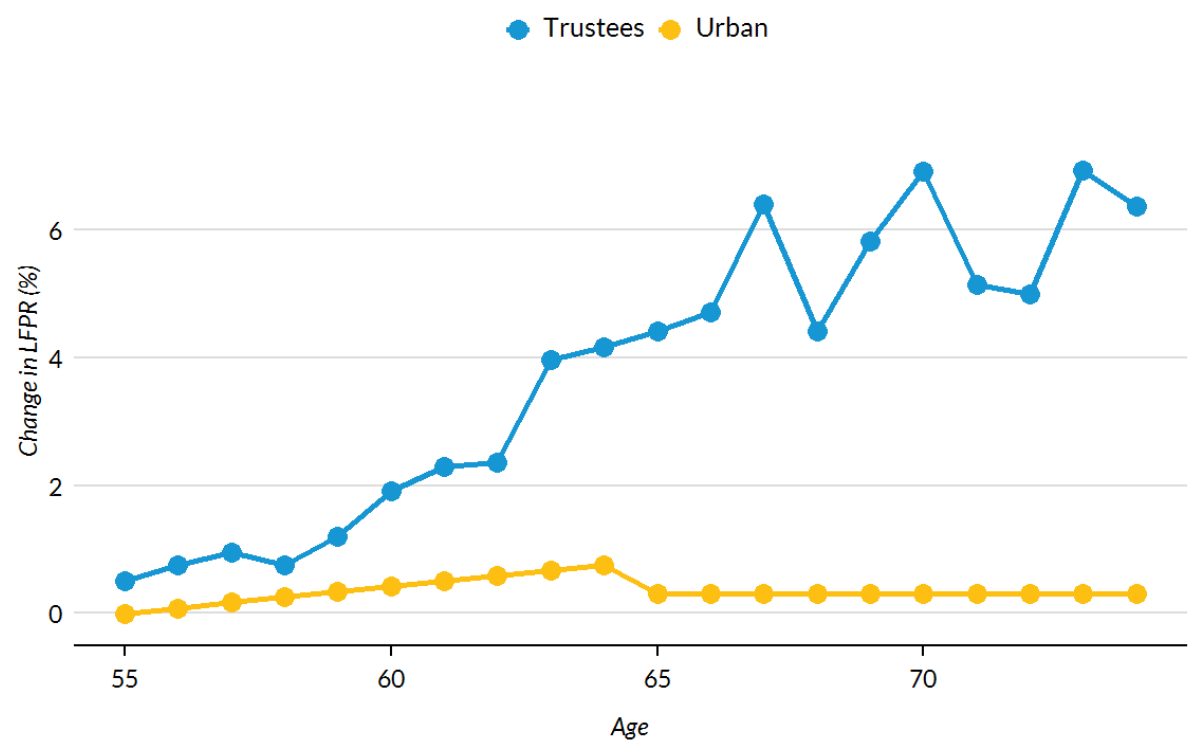

Notes: Trustees values were calculated based on their life-expectancy add factor, which was provided to us by the Social Security Administration. For each age, we found the year in which life expectancy is projected to increase by one year, found the add factor in that year, and divided it by the labor force participation in 2018 to obtain percent change. We used Chebyshev polynomials to interpolate values for non-integer years. Urban values were calculated based on the best fitting regressions in table 3 . For women ages 65 to 74 , we used the estimates for the $3^{\text {rd }}$ quartile of median household income. 


\section{Tables}

Table 1. Summary Statistics: Means and Standard Deviations by Age-Gender Group

\begin{tabular}{|c|c|c|c|c|c|c|c|c|}
\hline & \multicolumn{4}{|c|}{ Women } & \multicolumn{4}{|c|}{ Men } \\
\hline & \multicolumn{2}{|c|}{ Ages 55-64 } & \multicolumn{2}{|c|}{ Ages 65-74 } & \multicolumn{2}{|c|}{ Ages 55-64 } & \multicolumn{2}{|c|}{ Ages 65-74 } \\
\hline & Mean & SD & Mean & SD & Mean & SD & Mean & SD \\
\hline Labor force participation rate & 0.59 & 0.15 & 0.23 & 0.12 & 0.69 & 0.16 & 0.31 & 0.15 \\
\hline Life expectancy (years) & 27.52 & 2.97 & 19.76 & 2.54 & 27.55 & 2.96 & 19.84 & 2.53 \\
\hline Employment rate (ages 25-54) & 0.75 & 0.10 & 0.76 & 0.10 & 0.75 & 0.10 & 0.76 & 0.10 \\
\hline Share high-school or less & 0.43 & 0.17 & 0.42 & 0.17 & 0.43 & 0.17 & 0.41 & 0.17 \\
\hline Share ages 55-59 & 0.33 & 0.09 & 0.31 & 0.09 & 0.34 & 0.10 & 0.32 & 0.09 \\
\hline Share ages $62-64$ & 0.17 & 0.07 & 0.16 & 0.06 & 0.17 & 0.07 & 0.16 & 0.07 \\
\hline Share ages $70-74$ & 0.17 & 0.07 & 0.17 & 0.07 & 0.15 & 0.07 & 0.17 & 0.07 \\
\hline Share disabled & 0.13 & 0.05 & 0.13 & 0.05 & 0.13 & 0.05 & 0.13 & 0.05 \\
\hline Median household income (\$) & 58645 & 28471 & 60394 & 28514 & 58961 & 28502 & 61821 & 28861 \\
\hline Share non-Latinx White & 0.63 & 0.30 & 0.66 & 0.28 & 0.64 & 0.30 & 0.68 & 0.27 \\
\hline Share in poverty & 0.12 & 0.11 & 0.11 & 0.09 & 0.12 & 0.11 & 0.10 & 0.09 \\
\hline Census-tract population & 301.4 & 142.6 & 221.7 & 106.8 & 283.0 & 133.3 & 205.6 & 97.2 \\
\hline Number of tracts & \multicolumn{2}{|c|}{62,282} & \multicolumn{2}{|c|}{50,715} & \multicolumn{2}{|c|}{61,175} & \multicolumn{2}{|c|}{46,486} \\
\hline
\end{tabular}

Note: For each age-gender group, we dropped census tracts with less than 100 people in the group and census tracts with a zero labor force participation rate for the group.

Source: Authors' estimates from USALEEP and ACS (2011-2015) data. 
Table 2. Estimates of the Baseline Regression of Labor Force Participation

\begin{tabular}{|c|c|c|c|c|}
\hline & \multicolumn{2}{|l|}{ Women } & \multicolumn{2}{|l|}{ Men } \\
\hline & $55-64$ & $65-74$ & $55-64$ & $65-74$ \\
\hline Life expectancy & $\begin{array}{c}0.00260 * * * \\
(0.00043)\end{array}$ & $\begin{array}{c}-0.00242 * * \\
(0.00115)\end{array}$ & $\begin{array}{c}0.00972 * * * \\
(0.00040)\end{array}$ & $\begin{array}{c}0.01028 * * * \\
(0.00110)\end{array}$ \\
\hline $\begin{array}{l}\text { Employment rate (ages } 25- \\
54)\end{array}$ & $\begin{array}{c}0.70170 * * * \\
(0.01591)\end{array}$ & $\begin{array}{c}0.63177 * * * \\
(0.03428)\end{array}$ & $\begin{array}{c}0.95914 * * * \\
(0.01801)\end{array}$ & $\begin{array}{c}0.83636 * * * \\
(0.03614)\end{array}$ \\
\hline Share high-school or less & $\begin{array}{c}-0.33723 * * * \\
(0.00764)\end{array}$ & $\begin{array}{c}-0.62020 * * * \\
(0.01702)\end{array}$ & $\begin{array}{c}-0.28030 * * * \\
(0.00610)\end{array}$ & $\begin{array}{c}-0.76966 * * * \\
(0.01458)\end{array}$ \\
\hline Share ages 55-59 & $\begin{array}{c}0.15743 * * * \\
(0.01229)\end{array}$ & & $\begin{array}{c}0.15176 * * * \\
(0.01077)\end{array}$ & \\
\hline Share ages 62-64 & $\begin{array}{c}-0.24493 * * * \\
(0.01428)\end{array}$ & & $\begin{array}{c}-0.24035 * * * \\
(0.01263)\end{array}$ & \\
\hline Share ages $70-74$ & & $\begin{array}{c}-0.58147 * * * \\
(0.02030)\end{array}$ & & $\begin{array}{c}-0.51850 * * * \\
(0.01929)\end{array}$ \\
\hline $\begin{array}{l}\text { Urbanicity, large non- } \\
\text { metro }\end{array}$ & $\begin{array}{c}0.00227 \\
(0.00527)\end{array}$ & $\begin{array}{c}0.05482 * * * \\
(0.01399)\end{array}$ & $\begin{array}{l}0.00872 * \\
(0.00516)\end{array}$ & $\begin{array}{c}0.02829 * * \\
(0.01317)\end{array}$ \\
\hline $\begin{array}{l}\text { Urbanicity, small non- } \\
\text { metro }\end{array}$ & $\begin{array}{l}-0.01075^{*} \\
(0.00580)\end{array}$ & $\begin{array}{c}0.02314 \\
(0.01508)\end{array}$ & $\begin{array}{c}0.00137 \\
(0.00561)\end{array}$ & $\begin{array}{l}-0.01492 \\
(0.01422)\end{array}$ \\
\hline Intercept & $\begin{array}{c}-1.07155^{* * *} \\
(0.03121)\end{array}$ & $\begin{array}{c}-1.50049 * * * \\
(0.07745)\end{array}$ & $\begin{array}{c}-1.33430 * * * \\
(0.03396)\end{array}$ & $\begin{array}{c}-1.65354 * * * \\
(0.07982)\end{array}$ \\
\hline Observations & 62,262 & 50,703 & 61,155 & 46,475 \\
\hline $\mathrm{R}^{2}$ & 0.29321 & 0.14820 & 0.38409 & 0.23467 \\
\hline Adjusted $\mathrm{R}^{2}$ & 0.28472 & 0.13576 & 0.37655 & 0.22251 \\
\hline
\end{tabular}

Notes: $* \mathrm{p}<0.1 ; * * \mathrm{p}<0.05$; *** $\mathrm{p}<0.01$. Dependent variable is log labor force participation. Unit of observation is census tract. Regressions include state and commuting-zone fixed effects. Shares are expressed as percentages. Source: Authors' estimates. 
Table 3. Estimates of the Best-Fit Regressions of Labor Force Participation

\begin{tabular}{|c|c|c|c|c|}
\hline & \multicolumn{2}{|l|}{ Women } & \multicolumn{2}{|l|}{ Men } \\
\hline & $55-64$ & $65-74$ & $55-64$ & $65-74$ \\
\hline Life expectancy & $\begin{array}{c}0.02747 * * * \\
(0.00565)\end{array}$ & $\begin{array}{c}-0.00978^{* * *} \\
(0.00246)\end{array}$ & $\begin{array}{c}0.04512 * * * \\
(0.00483)\end{array}$ & $\begin{array}{c}0.03711 * * * \\
(0.01110)\end{array}$ \\
\hline Life expectancy squared & $\begin{array}{l}-0.00046 * * * \\
(0.00010)\end{array}$ & & $\begin{array}{c}-0.00071 * * * \\
(0.00008)\end{array}$ & $\begin{array}{c}-0.00059 * * \\
(0.00026)\end{array}$ \\
\hline $\begin{array}{l}\text { 2nd quartal of median } \\
\text { household income }\end{array}$ & $\begin{array}{c}0.06707 * * \\
(0.03393)\end{array}$ & $\begin{array}{l}-0.11251^{*} \\
(0.06241)\end{array}$ & & \\
\hline $\begin{array}{l}\text { 3rd quartal of median } \\
\text { household income }\end{array}$ & $\begin{array}{c}0.05197 \\
(0.03542)\end{array}$ & $\begin{array}{c}-0.27231 * * * \\
(0.06397)\end{array}$ & & \\
\hline $\begin{array}{l}\text { 4th quartal of median } \\
\text { household income }\end{array}$ & $\begin{array}{c}0.05412 \\
(0.03954)\end{array}$ & $\begin{array}{c}-0.27991 * * * \\
(0.06490)\end{array}$ & & \\
\hline Low employment area & & & $\begin{array}{c}0.02044 \\
(0.01889)\end{array}$ & $\begin{array}{c}0.20943 * * * \\
(0.04212)\end{array}$ \\
\hline $\begin{array}{l}\text { Employment rate (ages } 25 \text { - } \\
54 \text { ) }\end{array}$ & $\begin{array}{l}0.36172 * * * \\
(0.01741)\end{array}$ & $\begin{array}{c}0.43376 * * * \\
(0.04194)\end{array}$ & $\begin{array}{c}0.76528 * * * \\
(0.02978)\end{array}$ & $\begin{array}{c}0.55417 * * * \\
(0.05309)\end{array}$ \\
\hline Share high-school or less & $\begin{array}{c}-0.27900 * * * \\
(0.00861)\end{array}$ & $\begin{array}{c}-0.56588 * * * \\
(0.01896)\end{array}$ & $\begin{array}{l}-0.11581 * * * \\
(0.00731)\end{array}$ & $\begin{array}{c}-0.56460 * * * \\
(0.01719)\end{array}$ \\
\hline Share ages 55-59 & $\begin{array}{l}0.15282 * * * \\
(0.01210)\end{array}$ & & $\begin{array}{l}0.13281 * * * \\
(0.01035)\end{array}$ & \\
\hline Share ages $62-64$ & $\begin{array}{l}-0.23942 * * * \\
(0.01406)\end{array}$ & & $\begin{array}{c}-0.23236 * * * \\
(0.01221)\end{array}$ & \\
\hline Share ages 70-74 & & $\begin{array}{c}-0.57159 * * * \\
(0.02029)\end{array}$ & & $\begin{array}{c}-0.49389 * * * \\
(0.01918)\end{array}$ \\
\hline Share disabled & $\begin{array}{c}-0.76919 * * * \\
(0.03330)\end{array}$ & $\begin{array}{c}-0.90333 * * * \\
(0.07827)\end{array}$ & $\begin{array}{l}-1.11088^{* * *} \\
(0.03225)\end{array}$ & $\begin{array}{c}-1.24141^{* * *} \\
(0.08247)\end{array}$ \\
\hline $\begin{array}{l}\text { Log median household } \\
\text { income }\end{array}$ & & & $\begin{array}{l}0.07437 * * * \\
(0.00502)\end{array}$ & $\begin{array}{c}0.18603 * * * \\
(0.01301)\end{array}$ \\
\hline Share non-Latinx White & $\begin{array}{c}0.00338 \\
(0.00566)\end{array}$ & $\begin{array}{c}0.09526 * * * \\
(0.01403)\end{array}$ & $\begin{array}{l}0.05883 * * * \\
(0.00557)\end{array}$ & $\begin{array}{c}0.03439 * * \\
(0.01498)\end{array}$ \\
\hline Share in poverty & $\begin{array}{c}-0.38502 * * * \\
(0.02285)\end{array}$ & $\begin{array}{l}-0.05170 \\
(0.05321)\end{array}$ & $\begin{array}{c}-0.09064 * * * \\
(0.02201)\end{array}$ & $\begin{array}{c}0.25138 * * * \\
(0.05789)\end{array}$ \\
\hline $\begin{array}{l}\text { Urbanicity, large non- } \\
\text { metro }\end{array}$ & $\begin{array}{c}0.00513 \\
(0.00525)\end{array}$ & $\begin{array}{c}0.05814 * * * \\
(0.01403)\end{array}$ & $\begin{array}{c}0.00801 \\
(0.00504)\end{array}$ & $\begin{array}{c}0.00878 \\
(0.01313)\end{array}$ \\
\hline $\begin{array}{l}\text { Urbanicity, small non- } \\
\text { metro }\end{array}$ & $\begin{array}{l}-0.01047 * \\
(0.00573)\end{array}$ & $\begin{array}{l}0.02847^{*} \\
(0.01509)\end{array}$ & $\begin{array}{c}0.00305 \\
(0.00547)\end{array}$ & $\begin{array}{l}-0.00741 \\
(0.01412)\end{array}$ \\
\hline $\begin{array}{l}\text { Life expectancy X 2nd } \\
\text { quartile of HH income }\end{array}$ & $\begin{array}{l}-0.00207 \\
(0.00127)\end{array}$ & $\begin{array}{l}0.00601 * \\
(0.00323)\end{array}$ & & \\
\hline
\end{tabular}




\begin{tabular}{|c|c|c|c|c|}
\hline & \multicolumn{2}{|l|}{ Women } & \multicolumn{2}{|l|}{ Men } \\
\hline & $55-64$ & $65-74$ & $55-64$ & $65-74$ \\
\hline $\begin{array}{l}\text { Life expectancy X 3rd } \\
\text { quartile of } \mathrm{HH} \text { income }\end{array}$ & $\begin{array}{l}-0.00185 \\
(0.00130)\end{array}$ & $\begin{array}{c}0.01297 * * * \\
(0.00323)\end{array}$ & & \\
\hline $\begin{array}{l}\text { Life expectancy X 4th } \\
\text { quartile of } \mathrm{HH} \text { income }\end{array}$ & $\begin{array}{c}-0.00360 * * \\
(0.00142)\end{array}$ & $\begin{array}{c}0.01158 * * * \\
(0.00320)\end{array}$ & & \\
\hline $\begin{array}{l}\text { Life expectancy X low } \\
\text { employment area }\end{array}$ & & & $\begin{array}{c}0.00132 * * \\
(0.00065)\end{array}$ & $\begin{array}{c}-0.00882 * * * \\
(0.00204)\end{array}$ \\
\hline Intercept & $\begin{array}{c}-0.99426 * * * \\
(0.08420)\end{array}$ & $\begin{array}{c}-1.15432 * * * \\
(0.09430)\end{array}$ & $\begin{array}{c}-2.36063 * * * \\
(0.09738)\end{array}$ & $\begin{array}{c}-3.71780 * * * \\
(0.20944)\end{array}$ \\
\hline Observations & 62,262 & 50,703 & 61,155 & 46,475 \\
\hline $\mathrm{R}^{2}$ & 0.31574 & 0.15195 & 0.42941 & 0.25032 \\
\hline Adjusted $\mathrm{R}^{2}$ & 0.30741 & 0.13941 & 0.42236 & 0.23829 \\
\hline
\end{tabular}

Notes: $* \mathrm{p}<0.1 ; * * \mathrm{p}<0.05$; *** $\mathrm{p}<0.01$. Dependent variable is log labor force participation. Unit of observation is census tract. All regressions include state and commuting-zone fixed effects. Low employment areas have employment rate below the U.S. median employment rate. Shares are expressed as percentages.

Source: Authors' estimates. 


\section{RECENT WORKING PAPERS FROM THE CENTER FOR RETIREMENT RESEARCH AT BOSTON COLLEGE}

Do State and Local Government Employees Save Outside of Their Defined Benefit Plans When They Need To?

Laura D. Quinby and Geoffrey T. Sanzenbacher, November 2020

How Much Taxes Will Retirees Owe on Their Retirement Income?

Anqi Chen and Alicia H. Munnell, November 2020

A Behavioral Economics Assessment of SSDI Earnings Reporting Documents

Denise Hoffman, Jonah Deutsch, and Britta Seifert, November 2020

How Accurate Are Retirees' Assessments of Their Retirement Risk?

Wenliang Hou, July 2020

Is Nontraditional Work at Older Ages Associated with Better Retirement Security? Matthew S. Rutledge and Gal Wettstein, July 2020

New Insights on Self-Employment of Older Adults in the United States Joelle Abramowitz, July 2020

What Jobs Do Employers Want Older Workers to Do?

Alicia H. Munnell, Gal Wettstein, and Abigail N. Walters, June 2020

Technological Innovation and Labor Income Risk

Leonid Kogan, Dimitris Papanikolaou, Lawrence D. W. Schmidt, and Jae Song, June 2020

Are Older Nontraditional Workers Able to Find Health and Retirement Coverage? Matthew S. Rutledge, March 2020

Employer Perceptions of Older Workers - Surveys from 2019 and 2006 Alicia H. Munnell and Gal Wettstein, March 2020

Are Homeownership Patterns Stable Enough to Tap Home Equity?

Alicia H. Munnell, Abigail N. Walters, Anek Belbase, and Wenliang Hou, January 2020

The Impact of the Minimum Wage on DI Participation

Gary V. Engelhardt, January 2020

Scheduling Uncertainty and Employment of Young Adults with Disabilities Dara Lee Luca and Purvi Sevak, January 2020

All working papers are available on the Center for Retirement Research website (https://crr.bc.edu) and can be requested bye-mail (crr@bc.edu) or phone (617-552-1762). 